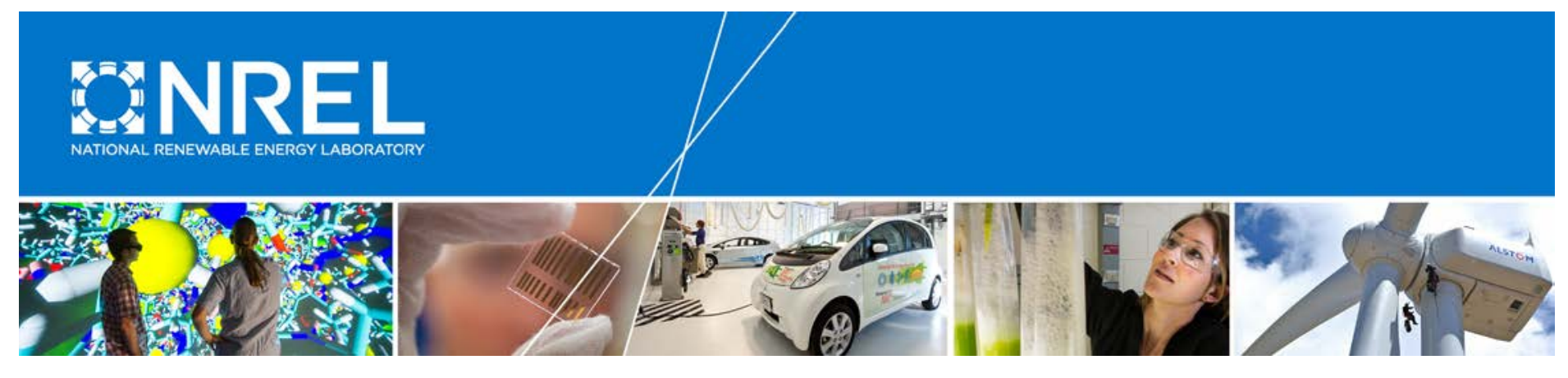

\title{
Time Series Analysis of Photovoltaic Soiling Station Data: Version 1.0, August 2017
}

Leonardo Micheli

National Renewable Energy Laboratory and

Colorado School of Mines

Daniel Ruth, Michael G. Deceglie, and Matthew Muller

National Renewable Energy Laboratory

NREL is a national laboratory of the U.S. Department of Energy Office of Energy Efficiency \& Renewable Energy Operated by the Alliance for Sustainable Energy, LLC

This report is available at no cost from the National Renewable Energy Laboratory (NREL) at www.nrel.gov/publications.

Technical Report

NREL/TP-5J00-69131

September 2017

Contract No. DE-AC36-08G028308 


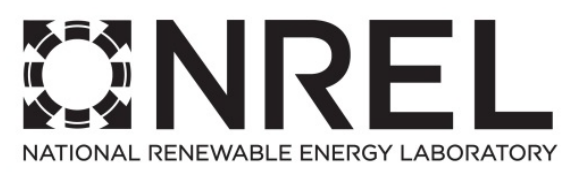

\section{Time Series Analysis of Photovoltaic Soiling Station Data: Version 1.0, August 2017}

Leonardo Micheli

National Renewable Energy Laboratory and Colorado School of Mines

Daniel Ruth, Michael G. Deceglie, and Matthew Muller

National Renewable Energy Laboratory

Prepared under Task No. SETP.10300.60.01.10

NREL is a national laboratory of the U.S. Department of Energy Office of Energy Efficiency \& Renewable Energy Operated by the Alliance for Sustainable Energy, LLC

This report is available at no cost from the National Renewable Energy Laboratory (NREL) at www.nrel.gov/publications.

National Renewable Energy Laboratory 15013 Denver West Parkway Golden, CO 80401 303-275-3000 • www.nrel.gov
Technical Report

NREL/TP-5J00-69131

September 2017

Contract No. DE-AC36-08GO28308 


\section{NOTICE}

This report was prepared as an account of work sponsored by an agency of the United States government. Neither the United States government nor any agency thereof, nor any of their employees, makes any warranty, express or implied, or assumes any legal liability or responsibility for the accuracy, completeness, or usefulness of any information, apparatus, product, or process disclosed, or represents that its use would not infringe privately owned rights. Reference herein to any specific commercial product, process, or service by trade name, trademark, manufacturer, or otherwise does not necessarily constitute or imply its endorsement, recommendation, or favoring by the United States government or any agency thereof. The views and opinions of authors expressed herein do not necessarily state or reflect those of the United States government or any agency thereof.

This report is available at no cost from the National Renewable Energy Laboratory (NREL) at www.nrel.gov/publications.

Available electronically at SciTech Connect http:/www.osti.gov/scitech

Available for a processing fee to U.S. Department of Energy and its contractors, in paper, from:

U.S. Department of Energy

Office of Scientific and Technical Information

P.O. Box 62

Oak Ridge, TN 37831-0062

OSTI http://www.osti.gov

Phone: 865.576.8401

Fax: 865.576.5728

Email: reports@osti.gov

Available for sale to the public, in paper, from:

U.S. Department of Commerce

National Technical Information Service

5301 Shawnee Road

Alexandria, VA 22312

NTIS http://www.ntis.gov

Phone: 800.553 .6847 or 703.605 .6000

Fax: 703.605.6900

Email: orders@ntis.gov 


\section{Preface}

This document presents time series data for a number of soiling stations measured by or made available to NREL. This work will be updated periodically when new datasets are available. 


\section{Acknowledgments}

This work was supported by the U.S. Department of Energy under Contract No. DE-AC3608GO28308 to the National Renewable Energy Laboratory. 


\section{Nomenclature and Acronyms}

Isc

NREL

POA

SRate

SRatio
Irradiance-corrected short-circuit current

National Renewable Energy Laboratory

Plane-of-array irradiance

Soiling Rate

Soiling Ratio 


\section{Executive Summary}

The time series data from PV soiling stations, operating in the USA, at different time periods are analyzed and presented. The current version of the paper includes twenty stations operating between 2013 and 2016, but the paper is intended to be periodically updated as more stations and more data become available. The challenges in working with soiling stations data are discussed, including measurement methodology, quality controls, and measurement uncertainty. The soiling profiles of the soiling stations are made available so that the PV community can make use of this data to guide operations and maintenance decisions, estimate soiling derate in performance models, and more generally come to a better understanding of the challenges associated with the variability of PV soiling. 


\section{Table of Contents}

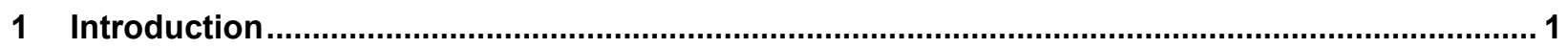

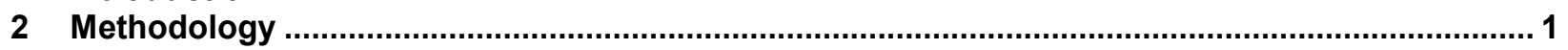

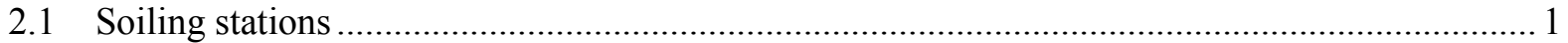

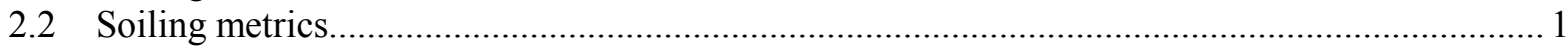

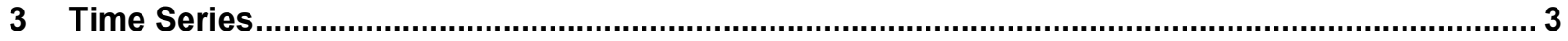

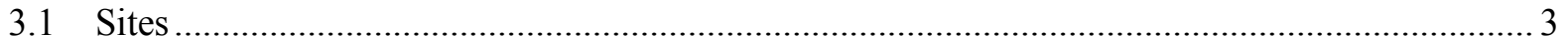

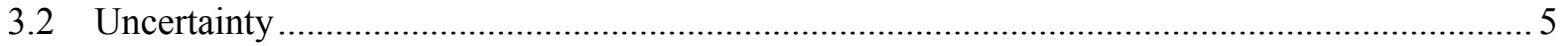

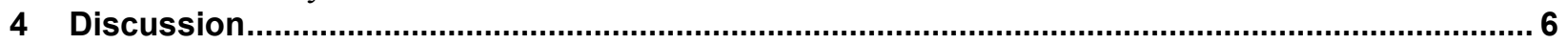

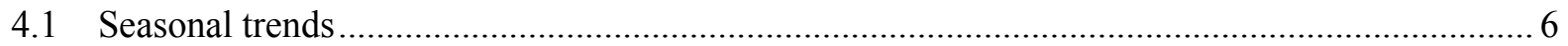

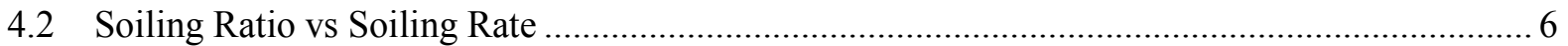

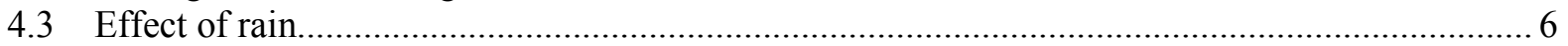

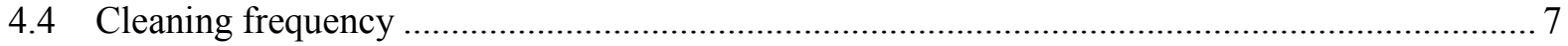

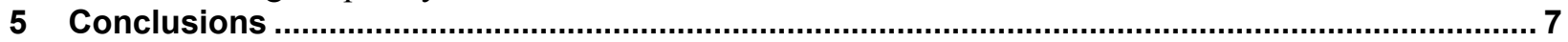

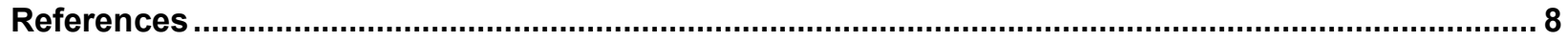

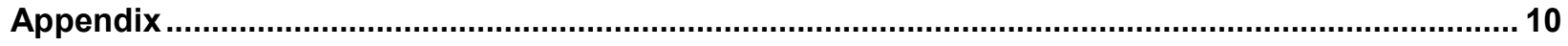




\section{List of Figures}

Figure 1. Flowchart describing the data processing employed to produce the plots and reported soiling metrics.

Figure 2. Time series of Sites 1 (top) and 15 (bottom). Both the sites show high uncertainity on the time series, for different reasons. The upward slope in (a) registered in Site 1 might be caused by shading or misalignment and suggests that data between May an November might not be reliable. In Site 15, the effect of noise is quite clear and might have biased the result............ 5

Figure 3. Soiling ratio profile and difference between the current outputs of the two PV devices in Site 7 between August and September 2015. The cleaning events are highlighted by white marks: when the control cell is cleaned, the difference between its current and the soiled cell's current increases. The current data shown in the figure are not irradiance-weighted.

\section{List of Tables}

Table 1. List of sites, inclusive of dates of operations, nearest town, county, state, brief description of the location, average SRatio and SRate. Dates are reported in $\mathrm{mm} / \mathrm{dd} /$ yyyy format. The tracking system is specified as well: single axis systems rotate around the horizontal N-S axis. The "Plot" column indicates if the time series is reported $(\checkmark)$, is biased by temporary shading or misalignment $(\mathrm{S})$ or is affected by severe noise $(\mathrm{N})$. 


\section{Introduction}

Soiling stations have been the most relied upon method to quantify the soiling occurring at a PV site, so far. The outputs of a cleaned and a soiled PV cell (or module) are compared to evaluate the impact that soiling would have on PV systems. Soiling stations, or the principle of a clean and a soiled device, have been used by a number of studies available in literature [1]-[7]. In this paper, the time series data from soiling stations (shared with NREL or measured by NREL) are analyzed and the plots representing this data are made available so that the community can better understand how soiling may effect PV plant performance in relation to the given sites. Additional sites will be added to this document as they become available to NREL and go through necessary quality checks.

\section{Methodology}

\subsection{Soiling stations}

Each soiling station is made of at least two PV devices (cells or modules) and in some cases meteorological data is also measured at the site. Although the meteorological data is not presented here, when available, it has been used in quality checking the performance of the soiling station. All the soiling station data have been converted and analyzed as daily values. The same analysis methodology has been applied to each soiling station. In order to remove the shading occurring at some stations [6], only data recorded at 12:00 PM and 1:00 PM have been used. Moreover, only irradiances $\geq 500 \mathrm{~W} / \mathrm{m}^{2}$ have been then considered for the calculation of the daily values.

\subsection{Soiling metrics}

The soiling accumulated on the PV devices at each soiling station has been quantified through two factors, as described below:

- Soiling ratio (SRatio): ratio of the short circuit current of the soiled cell to the short circuit current of the clean cell under the same conditions (dimensionless).

- Soiling rate (SRate): daily derate of soiling ratio, when no cleaning occurs on the cells (fraction per day).

All the analyses have been based on the irradiance-corrected short-circuit current outputs of each PV device. The daily average current (Isc(i)) has been calculated as follow [7]:

$$
I s c(i)=\frac{\sum_{h=12}^{13} I s c_{h}(h) \cdot \frac{1000 \mathrm{~W} / \mathrm{m}^{2}}{P O A(h)}}{n}
$$

where $\operatorname{Isc}_{h}(h)$ is the mean hourly short-circuit current measured by the PV device, POA is the mean hourly plane of array irradiance, $h$ are the hours (12PM and $1 \mathrm{PM})$, and $n$ is the number of hours used for the daily average. The irradiance correction equally weights multiple data points on the same day. 
The daily soiling ratio of each $\mathrm{i}^{\text {th }}$-day have been calculated as follows:

$$
\text { daily } \operatorname{SRatio}(i)=\frac{I S c_{\text {soiled }}(i)}{I S c_{\text {cleaned }}(i)}
$$

where Isc $_{\text {soiled }}$ and Isc $_{\text {cleaned }}$ are the irradiance-corrected average daily short-circuit currents of the dirty and clean cells, respectively.

In order to minimize noise and to present the clearest possible trends in the plots, 11-day moving medians have been calculated for the daily SRatio [8]. The median SRatio value for the $i^{\text {th }}$ day has been calculated using the data from the $\mathrm{i}^{\text {th }}-5$ to the $\mathrm{i}^{\text {th }}+5$ day. For median calculation purposes only, missing daily SRatio values have been filled with the daily SRatio of the previous available day. After the calculation of the moving median, an additive offset correction has been applied to the whole dataset, in order to set the average median-filtered SRatio of the first week at 1. Further calibrations have been applied when, both reference cells are assumed clean, and a SRatio different than 1 was recorded. The calibration is essentially an offset correction which has been propagated until the end of the data collection or, if any, until an additional calibration. All the SRatios shown in the time series plots are based on 11-day moving median. The overall SRatios reported for each site, however, are the averages of the daily calibrated irradiancecorrected SRatio (not the running median).

The soiling rates have been extracted from the SRatio datasets, prior to applying the moving median filter, using the methodology proposed by Ref. [9]. Indeed, the Theil-Sen regression, used to define the soiling rates, is a robust method able to reduce the impact of outliers. The precipitation data use to determine the dry periods have been extracted from PRISM database [10]-[12] because they have been previously found to have better correlation with SRatios than rain gauge data [7]. In one case (Site 9), rain gauge data have been used, since PRISM data were not available. The method in Ref. [9] calculates the soiling rate for each dry period of at least 14 days as identified from the rain data. In some cases, a positive shift in the SRatio profile is found even if no rain has occurred (such as in (A) and (B) in Site 10 plot). In order not to include positive shifts due to manual cleanings of the "unwashed" cell in the calculation of the SRates, each SRatio profile has been visually checked and the end of the dry period has been manually imposed when an inadvertent cleaning has been suspected. Dry periods with positive slopes (suggesting the unwashed cell is becoming cleaner over time) are also discarded. To further filter out erroneous soiling periods, the $R^{2}$ correlation relating soiling ratio values to the correlation determined with the Theil-Sen method is calculated for each site. To ensure that the reported soiling rates capture the observed trends in the soiling ratio, soiling periods for which this $R^{2}$ correlation is less than 0.1 are discarded. A summary of all the steps followed in the data process is reported in Figure 1. 
Soiling ratio profile obtained by dividing daily unwashed current by washed current. Low irradiance data are filtered out.

The median-filtered soiling ratio is calculated, initially forward-filling and then removing any missing values.

A calibration is applied to the raw SRatio series, such that the first seven valid days of the moving median average to one. The calibration is propagated forward through the raw SRatio data until a future calibration day.

At each of the specified "SRatio re-calibration day", the data is recalibrated such that the first seven valid days after the re-calibration day in the median-filtered data average to one. The fully calibrated SRatio time series is used for determining the final moving median and for calculated soiling rates.

For each dry period of at least 14 days (as determined by just the PRISM data, if available, or the rain gauge data), the soiling rate is extracted by using the Theil-Sen method on the calibrated SRatio data. The calibrated SRatio data are analyzed separately for each dry period when applying the Theil-Sen fit for the given period. Each period was visually inspected to remove incorrect cleanings or shifts in the SRatio that were not associated with rain.

The overall soiling ratio is obtained as the average of the calibrated SRatio values. The overall soiling rate for the site is calculated as the median of soiling rates for all relevant dry periods (at least 14 days, not too many missing days, must have negative slope, $R^{2}$ for fit $>0.1$ ).

\section{Figure 1. Flowchart describing the data processing employed to produce the plots and reported soiling metrics.}

\section{Time Series}

\subsection{Sites}

Sites are numbered from 1 to 19 (Table 1), with Site 5 having a fixed and a tracked soiling station. The time series of each site is individually shown at the end of this report, containing:

- State, county, and nearest town to the installation;

- Soiling ratio and soiling rate;

- Dates of operation;

- Plot of the time series.

Each plot reports the daily soiling ratios (black solid line, left axis), the mean soiling ratio (horizontal broken line, left axis) and the PRISM accumulated daily precipitations, in $\mathrm{mm} /$ day (blue dots, right axis). 
Table 1. List of sites, inclusive of dates of operations, nearest town, county, state, average SRatio and SRate. Dates are reported in $\mathrm{mm} / \mathrm{dd} / \mathrm{yyyy}$ format. The tracking system is specified as well: single axis systems rotate around the horizontal N-S axis. The "Plot" column indicates if the time series is reported $(\checkmark)$, is biased by temporary shading or misalignment $(S)$ or is affected by severe noise (N).

\begin{tabular}{|c|c|c|c|c|c|c|c|}
\hline Site & Time period & $\begin{array}{l}\text { Nearest } \\
\text { town }\end{array}$ & $\begin{array}{l}\text { County, } \\
\text { State }\end{array}$ & $\begin{array}{l}\text { Tracking (Tilt } \\
\text { [deg]) }\end{array}$ & $\begin{array}{l}\text { SRatio } \\
{[\%]}\end{array}$ & $\begin{array}{l}\text { SRate } \\
\text { [\%/day] }\end{array}$ & Plot \\
\hline 1 & $\begin{array}{l}08 / 29 / 2014 \text { to } \\
05 / 31 / 2016\end{array}$ & Springer, NM & Colfax, NM & Fixed (25) & $>99$ & N.A. & $S$ \\
\hline 2 & $\begin{array}{l}06 / 01 / 2014 \text { to } \\
01 / 01 / 2016\end{array}$ & Deming, NM & Luna, NM & Single Axis & $>99$ & -0.03 & $\mathrm{~N}$ \\
\hline 3 & $\begin{array}{l}12 / 30 / 2014 \text { to } \\
01 / 01 / 2016\end{array}$ & Calipatria, CA & Imperial, CA & Single Axis & 97.5 & -0.10 & $\checkmark$ \\
\hline 4 & $\begin{array}{l}\text { 06/18/2015 to } \\
06 / 30 / 2016\end{array}$ & Mendota, CA & Fresno, CA & Single Axis & 98.2 & -0.06 & $\checkmark$ \\
\hline $5 \mathrm{~A}$ & \begin{tabular}{|l|}
$02 / 01 / 2013$ \\
$01 / 01 / 2016$ \\
\end{tabular} & Neenach, CA & $\begin{array}{l}\text { Los Angeles, } \\
\text { CA }\end{array}$ & Fixed (25) & 98.6 & -0.04 & $\checkmark$ \\
\hline $5 B$ & $\begin{array}{l}07 / 01 / 2014 \text { to } \\
01 / 01 / 2016\end{array}$ & Neenach, CA & $\begin{array}{l}\text { Los Angeles, } \\
\text { CA }\end{array}$ & Single Axis & $>99$ & -0.04 & $\checkmark$ \\
\hline 6 & $\begin{array}{l}\text { 01/30/2014 to } \\
06 / 30 / 2016\end{array}$ & Hyder, AZ & Yuma, AZ & Fixed (20) & $>99$ & -0.02 & $\checkmark$ \\
\hline 7 & \begin{tabular}{|l|}
$05 / 31 / 2015$ \\
$07 / 31 / 2016$
\end{tabular} & $\begin{array}{l}\text { California } \\
\text { Valley, CA }\end{array}$ & $\begin{array}{l}\text { San Luis } \\
\text { Obispo, CA }\end{array}$ & Single Axis & $>99$ & -0.08 & $\checkmark$ \\
\hline 8 & \begin{tabular}{|l|}
$05 / 01 / 2013$ to \\
$01 / 01 / 2016$ \\
\end{tabular} & $\begin{array}{l}\text { Avra Valley, } \\
\text { AZ }\end{array}$ & Pima, AZ & Single Axis & $>99$ & -0.05 & $\checkmark$ \\
\hline 9 & \begin{tabular}{|l|}
$05 / 08 / 2015$ to \\
$12 / 09 / 2015$ \\
\end{tabular} & Waipahu, HI & Honolulu, HI & Fixed (20) & $>99$ & N.A. & $\mathrm{N}$ \\
\hline 10 & $\begin{array}{l}02 / 01 / 2013 \text { to } \\
06 / 01 / 2014\end{array}$ & Meridian, CA & Kern, CA & Fixed (20) & 95.4 & -0.24 & $\checkmark$ \\
\hline 11 & $\begin{array}{l}02 / 01 / 2013 \text { to } \\
10 / 31 / 2014\end{array}$ & Lamont, CA & Kern, CA & Fixed (20) & 94.9 & -0.13 & $\checkmark$ \\
\hline 12 & \begin{tabular}{|l|}
$09 / 01 / 2014$ to \\
$08 / 12 / 2015$
\end{tabular} & Hemet, CA & Riverside, CA & Fixed (20) & 98.0 & -0.16 & $\checkmark$ \\
\hline 13 & \begin{tabular}{|l|}
$07 / 01 / 2014$ to \\
$08 / 01 / 2015$ \\
\end{tabular} & Pueblo, CO & Pueblo, CO & Fixed (45) & 98.8 & -0.04 & $S$ \\
\hline 14 & $\begin{array}{l}12 / 17 / 2014 \text { to } \\
12 / 09 / 2015\end{array}$ & Notrees, TX & Winkler, TX & Fixed (20) & $>99$ & -0.15 & $\mathrm{~N}$ \\
\hline 15 & \begin{tabular}{|l|}
$04 / 01 / 2014$ to \\
$05 / 01 / 2015$
\end{tabular} & Cedar City, UT & Iron, UT & Fixed (45) & $>99$ & N.A. & $\mathrm{N}$ \\
\hline 16 & $\begin{array}{l}12 / 01 / 2013 \text { to } \\
12 / 20 / 2014\end{array}$ & Actis, CA & Kern, CA & Fixed (20) & 98.6 & -0.03 & $\checkmark$ \\
\hline 17 & $\begin{array}{l}12 / 13 / 2013 \text { to } \\
03 / 01 / 2015\end{array}$ & Lakeland, FL & Polk, FL & Fixed (20) & $>99$ & -0.03 & $N$ \\
\hline 18 & \begin{tabular}{|l|}
$05 / 21 / 2013$ \\
$05 / 20 / 2016$ \\
\end{tabular} & Watkins, CO & Adams, CO & Fixed (10) & $>99$ & -0.04 & $S$ \\
\hline 19 & $\begin{array}{l}\text { 12/07/2014 to } \\
09 / 22 / 2016\end{array}$ & Gilbert, AZ & Maricopa, AZ & Fixed (35) & $>99$ & -0.06 & $\checkmark$ \\
\hline
\end{tabular}




\subsection{Uncertainty}

Sites with soiling ratios above $99 \%$ have all been classified as "SRatio $>99 \%$ " sites. These low soiling sites have been found to be affected by two issues which make it difficult to accurately determine an exact value for the soiling ratio. Examples are shown in Figure 2.
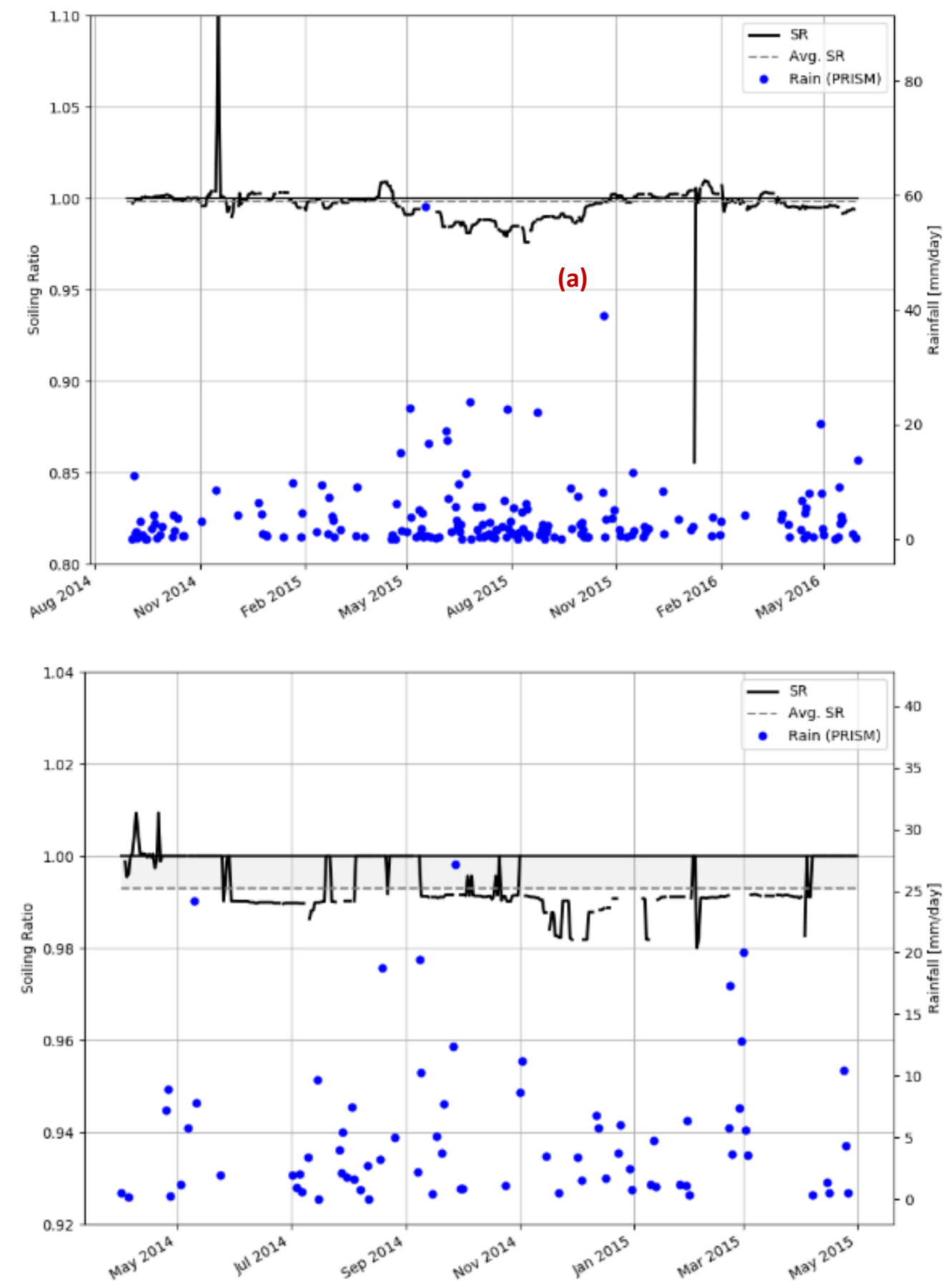

Figure 2. Time series of Sites 1 (top) and 15 (bottom). Both the sites show high uncertainity on the time series, for different reasons. The upward slope in (a) registered in Site 1 might be caused by shading or misalignment and suggests that data between May an November might not be reliable.

In Site 15, the effect of noise is quite clear and might have biased the result. 
Firstly, the measurements can be strongly biased by seasonal variation that cannot be confirmed to be soiling related. Possible explanations are obstructions resulting in seasonal shading or performance variation resulting from misalignment of the two PV devices. These sites are marked with an "S" in the "Plot" column of Table 1.

Secondly, the low soiling measurements have a high noise to soiling ratio, which, in some cases, can be larger than 1 [13]. Sites affected by severe noise are marked with "N" in the "Plot" column of Table 1. The plots of the "S" or the "N" marked sites have not been reported as the graphs are believed to provide no clear information beyond the values reported in Table 1 .

In some cases, it has not been possible to determine an average soiling rate ("N.A." in Table 1). This is due either to the short dry periods experienced by the site or by the high uncertainty found while fitting the data with the Theil-Sen method.

\section{Discussion}

The analysis of the time series leads to some interesting results, which should be further investigated in the future.

\subsection{Seasonal trends}

The soiling ratio profile does not necessarily have a consistent behavior and seasonal increases in soiling can be results of local temporary activities, such as farming, tilling or construction works [14]. Site 3 shows a consistent soiling rate across the investigated period, with a rise in soiling ratio generally for rainfalls above $1 \mathrm{~mm}$ /day. On the other hand, Site 12 is characterized by low soiling for most of the time, but its soiling profile is affected by construction ongoing adjacent to the site in the period between May and July 2015. Similarly, Site 16 has a higher soiling rate between September and November, and a lower one the rest of the year.

\subsection{Soiling Ratio vs Soiling Rate}

Even if most of the sites show a consistent soiling rate, there is not necessarily a direct relation with the soiling ratio and, thus, with the losses. For example, the soiling rate for Site 3 represents lower soiling per day but has a greater total soiling loss (soiling ratio) as compared to than 12 . Site 3 is in a dry location and experiences long and regular dry periods, where losses are likely to accumulate, while Site 12 alternates between a wet season, with limited soiling, and a dry season, where heavy soiling is more likely to occur. Therefore, the determination of soiling losses should not only rely on the quantification of the soiling rates, but might require a more accurate analysis of the performance profile [8].

\subsection{Effect of rain}

It is not possible to consistently identify a rain threshold for which the PV devices are cleaned, when rains are reported using a $\mathrm{mm}$ /day unit. In Site 4 , similar rainfall events produce different impacts on the soiling ratios: the rainfalls in (B), $0.22 \mathrm{~mm} /$ day, does not have any cleaning effect, while the rainfall in (C), $0.34 \mathrm{~mm} /$ day, show a raise in soiling ratio. Moreover some sites (Site 4 in $\mathrm{C}$, Site $5 \mathrm{~A}$ in $\mathrm{A}$ ) show that, after a rainfall with cleaning effect, the soiling ratio does not necessarily move back to 1 . 


\subsection{Cleaning frequency}

The cleaning frequency of the clean cell has a non-negligible impact on the analysis of data recorded by soiling stations. Clear steps due to the frequency of the cleaning schedule are visible during the high soiling period in Site 7 and Site 10. The drop in performance registered in (A) for Site 4 might also be due to the cleaning of the control cell. Indeed, during the time period between two cleanings, the two PV devices soil at similar rates, resulting in a flat SRatio, which is no longer a real measure of the soiling occurring on the soiled device. As soon as cleaning is performed, the SRatio drops, showing a real value of the ratio of the outputs of a soiled and a clean cell. The stepped profile shown in Figure 3 is a result of cleaning frequency at this site. The longer the period between cleanings, the larger are the steps for the cleaning event. The true soiling ratio in the period between cleanings is unknown, thus increasing the uncertainty. Corrective algorithms and the uncertainty due to the cleaning schedule are investigated in Ref. [13].

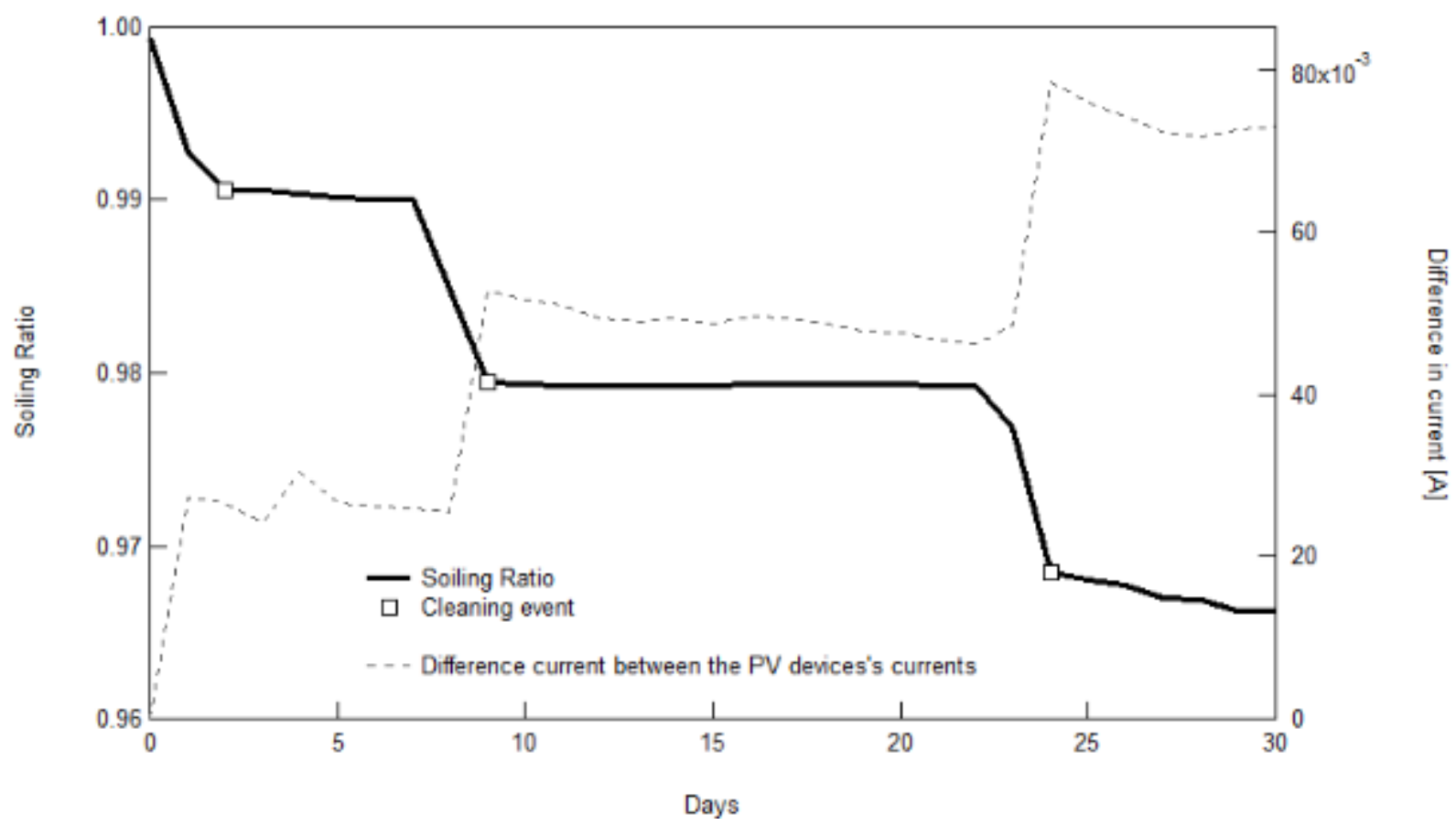

Figure 3. Soiling ratio profile and difference between the current outputs of the two PV devices in Site 7 between August and September 2015. The cleaning events are highlighted by white marks: when the control cell is cleaned, the difference between its current and the soiled cell's current increases. The current data shown in the figure are not irradiance-weighted.

In some soiling stations, it may happen that the wrong cell is accidentally cleaned. In Site 3 , an erroneous manual cleaning might have occurred on 11/28/2015 (A). There is a rise in the soiled cell current and no rains are reported either by PRISM or the rain gauge data. Similarly, the rise in soiling ratio marked as A and B in Site 10 might be due to an erroneous manual cleaning.

\section{Conclusions}

Data from PV soiling stations installed in the USA are analyzed, quality checked, and the resulting time series of the soiling ratio are plotted and made available for use by the PV 
community. The methodology employed to extract the soiling ratios and the soiling rates is described, and the main issues that can affect the analysis of the time series are discussed. Indeed, low soiling sites (SRatio $>99 \%$ ) are found to be more exposed to measurement noise, which can dramatically increase the uncertainty. The analysis of the time series resulted in a number of observations which are shared with the community. The soiling profile of each site is affected both by the soiling rate, which can vary during the year, and by the rainfall pattern. No clear threshold at which rainfalls have a cleaning impact on the station could be identified. The soiling rate and the soiling ratio do not directly correlate with each other and therefore caution should be taken to not rely on just one of the given metrics. It has also been shown that the cleaning frequency has a non-negligible impact on the soiling ratio profile: the longer number of days occurring between cleaning, the higher the uncertainty on the soiling ratio. It is recommended that cleaning of soiling stations should be done on a daily basis to minimize uncertainty of the reported metrics. Soiling can vary dramatically from year-to-year and therefore the time series presented in this paper provide no guarantees of future site soiling losses.

\section{References}

[1] G. Tamizhmani, B. King, A. Venkatesan, C. Deline, A. Pavgi, S. Tatapudi, J. Kuitche, A. Chokor, and M. El Asmar, "Regional Soiling Stations for PV: Soling Loss Analysis," in 2016 IEEE 43rd Photovoltaic Specialist Conference (PVSC), 2016, pp. 1741-1746.

[2] M. Gostein, T. Duster, and C. Thuman, "Accurately Measuring PV Soiling Losses With Soiling Station Employing Module Power Measurements," in IEEE 42nd Photovoltaic Specialist Conference (PVSC), 2015.

[3] M. Gostein, B. Littmann, J. R. Caron, and L. Dunn, "Comparing PV power plant soiling measurements extracted from PV module irradiance and power measurements," 2013 IEEE 39th Photovolt. Spec. Conf., no. 1, pp. 3004-3009, 2013.

[4] M. Gostein, J. R. Caron, and B. Littmann, "Measuring soiling losses at utility-scale PV power plants," 2014 IEEE 40th Photovolt. Spec. Conf., pp. 0885-0890, 2014.

[5] B. King, G. Tamizhmani, S. Tatapudi, V. Rajasekar, and S. Boppana, "Regional soiling stations for PV: Design, calibration and installation," 2015 IEEE 42nd Photovolt. Spec. Conf. PVSC 2015, pp. 1-4, 2015.

[6] L. Micheli, M. Muller, and S. Kurtz, "Determining the effects of environment and atmospheric parameters on PV field performance," in 2016 IEEE 43rd Photovoltaic Specialist Conference (PVSC), 2016, pp. 1724 - 1729.

[7] L. Micheli and M. Muller, "An investigation of the key parameters for predicting PV soiling losses," Prog. Photovoltaics Res. Appl., vol. 25, no. 4, pp. 291-307, Apr. 2017.

[8] M. G. Deceglie, L. Micheli, and M. Muller, "Quantifying Year-to-Year Variations in Solar Panel Soiling from PV Energy-Production Data," in 2017 IEEE 44th Photovoltaic Specialist Conference (PVSC), 2017. 
[9] M. G. Deceglie, M. Muller, Z. Defreitas, and S. Kurtz, "A Scalable Method for Extracting Soiling Rates from PV Production Data," in 2016 IEEE 43rd Photovoltaic Specialist Conference (PVSC), 2016.

[10] M. Di Luzio, G. L. Johnson, C. Daly, J. K. Eischeid, and J. G. Arnold, "Constructing retrospective gridded daily precipitation and temperature datasets for the conterminous United States," J. Appl. Meteorol. Climatol., vol. 47, no. 2, pp. 475-497, 2008.

[11] C. Daly, J. I. Smith, and K. V. Olson, Mapping atmospheric moisture climatologies across the conterminous United States, vol. 10, no. 10. 2015.

[12] PRISM Climate Group - Oregon State University, "PRISM Gridded Climate Data." [Online]. Available: http://prism.oregonstate.edu. [Accessed: 03-Jun-2017].

[13] M. Muller, L. Micheli, and A. A. Martinez-Morales, "A Method to Extract Soiling Loss Data From Soiling Stations with Imperfect Cleaning Schedules," in 2017 IEEE 44th Photovoltaic Specialist Conference (PVSC), 2017.

[14] L. Micheli, D. Ruth, and M. Muller, "Seasonal trends of soiling on Photovoltaic systems," in 2017 IEEE 44th Photovoltaic Specialist Conference (PVSC), 2017. 


\section{Appendix}

\section{Site 3 - Imperial County, Calipatria, CA}

Soiling Ratio $=97.5 \%$ | Soiling Rate $=-0.10 \% /$ day

December 30, 2014 to January 01, 2016

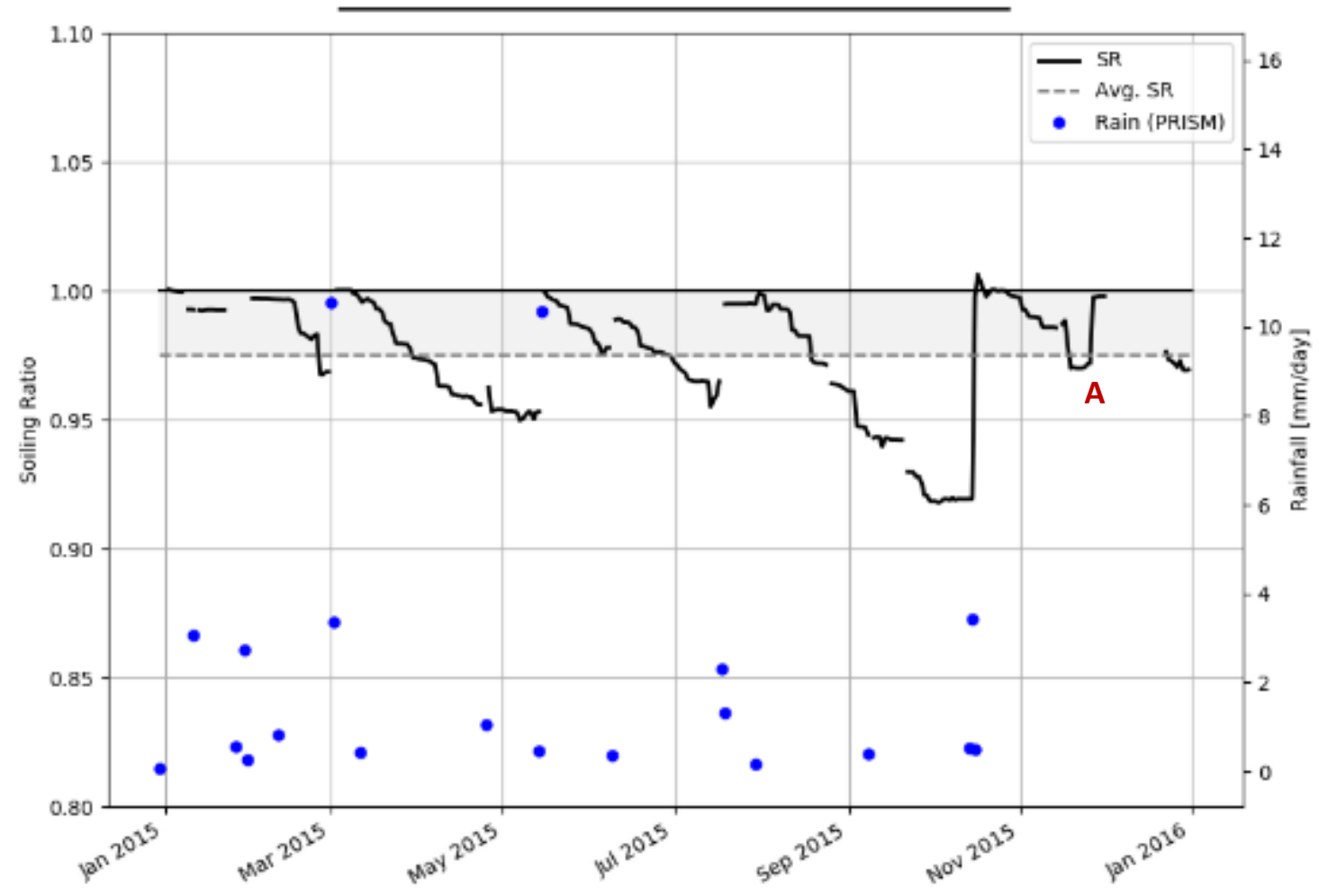




\section{Site 4 - Fresno County, Mendota, CA}

Soiling Ratio $=98.2 \%$ | Soiling Rate $=-0.06 \% /$ day

May 18, 2015 to June 30, 2016

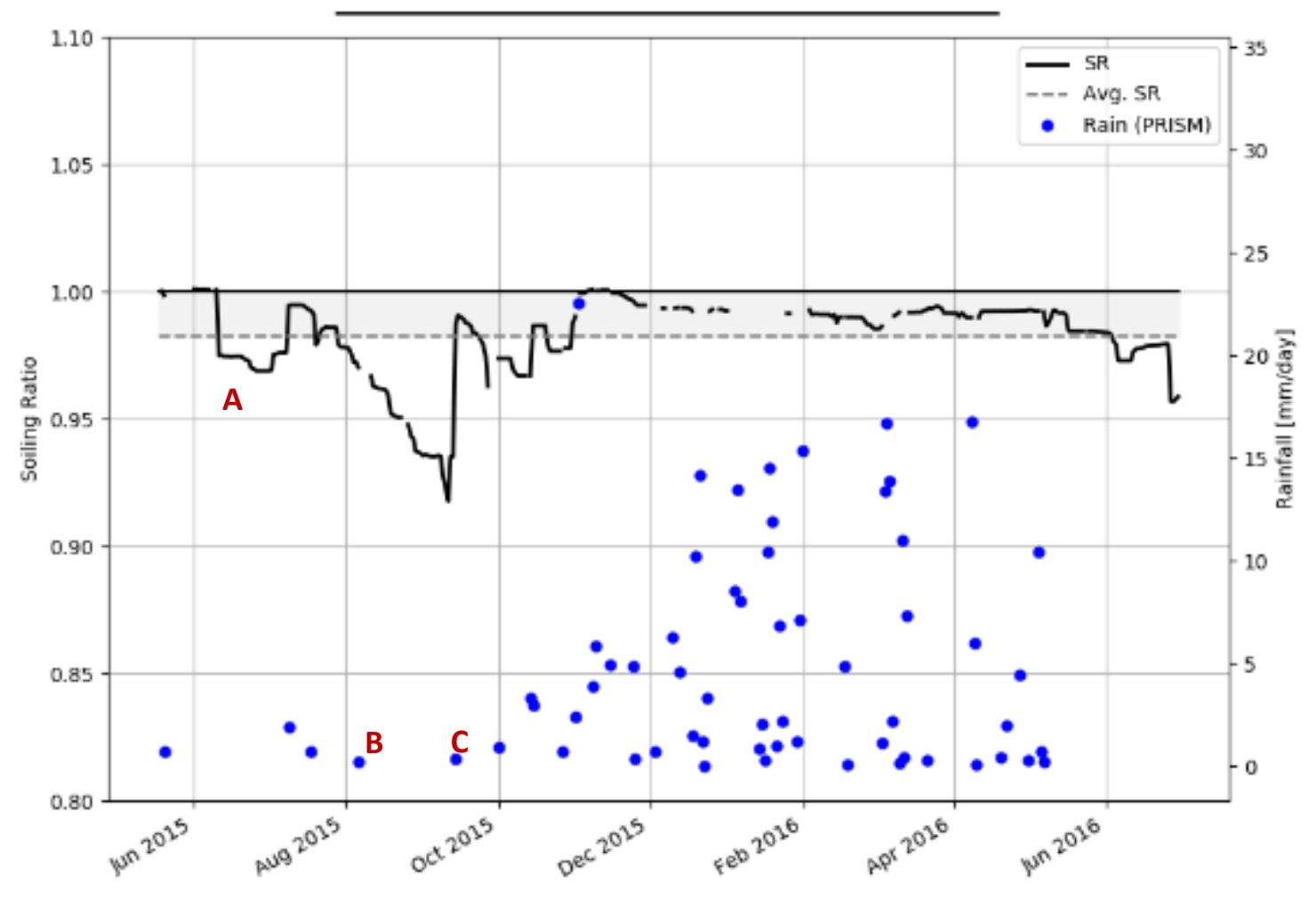




\section{Site 5A - Los Angeles County, Neenach, CA}

Soiling Ratio $=98.6 \%$ | Soiling Rate $=-0.04 \% /$ day

February 01, 2013 to June 30, 2015

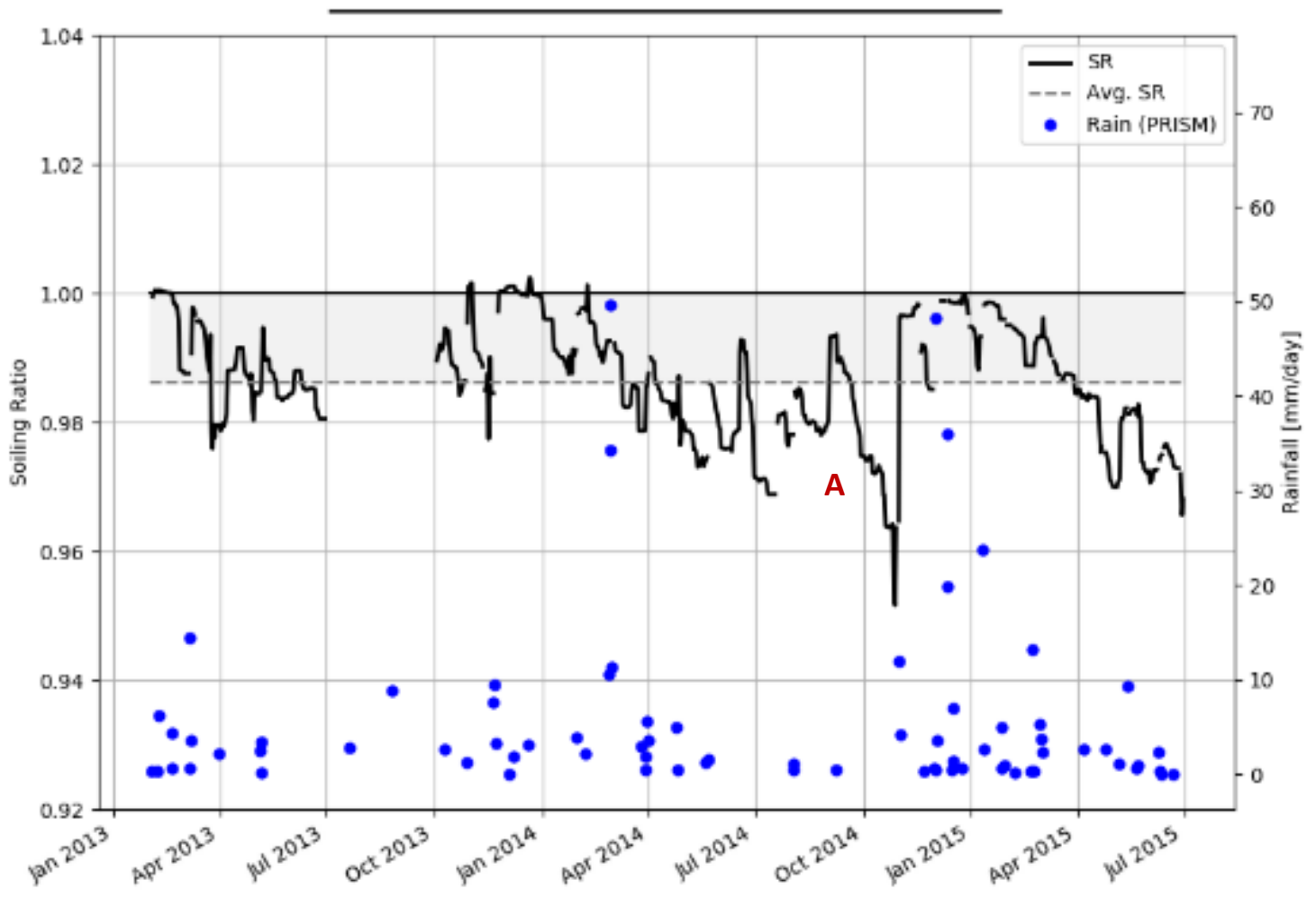




\section{Site 5B - Los Angeles County, Neenach, CA}

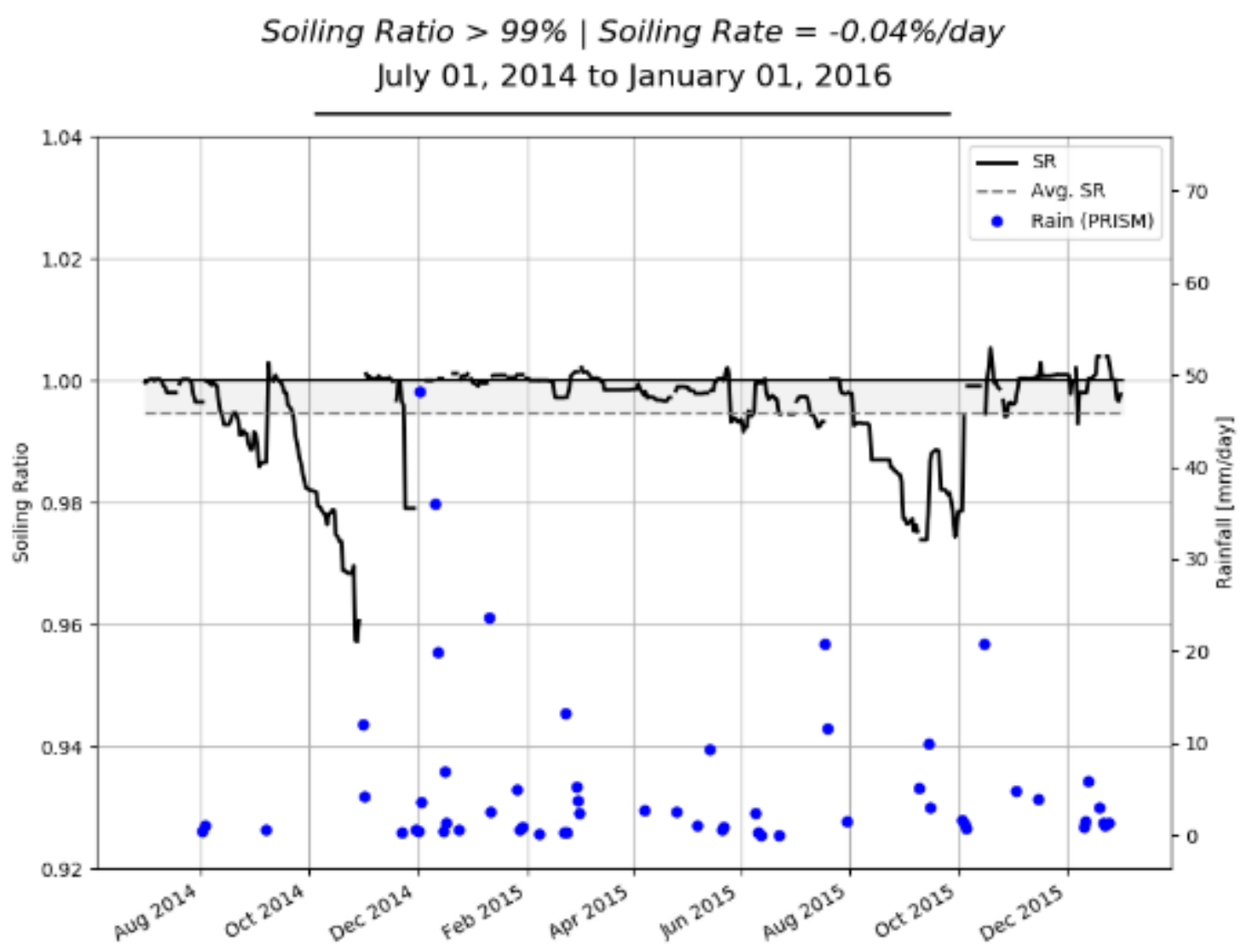




\section{Site 6 - Yuma County, Hyder, AZ}

Soiling Ratio > 99\% | Soiling Rate $=-0.02 \% /$ day

January 30, 2014 to June 30, 2016

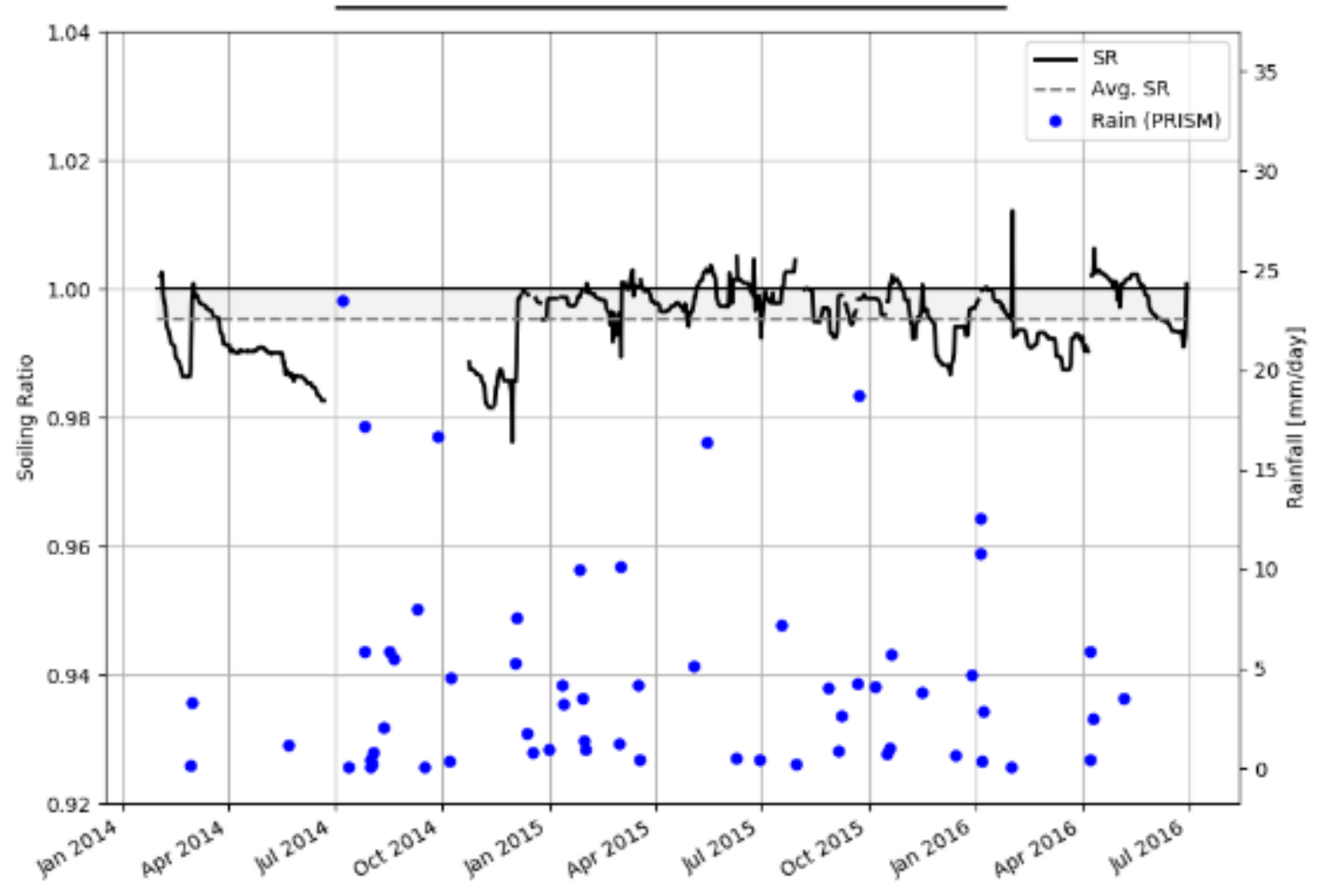




\section{Site 7 - San Luis Obispo County, California Valley, CA}

Soiling Ratio > 99\% | Soiling Rate $=-0.08 \% /$ day

May 31, 2015 to July 31, 2016

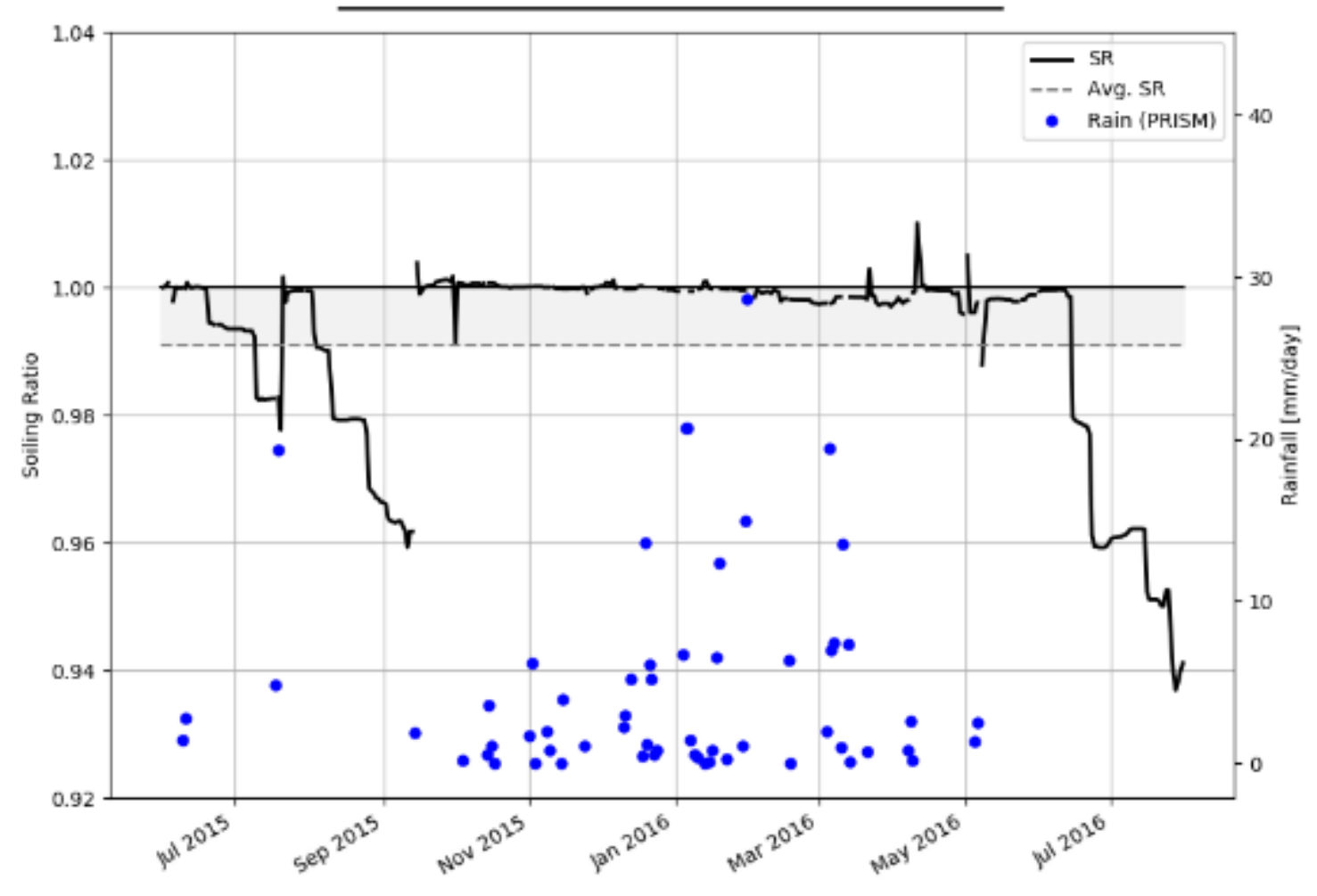




\section{Site 8 - Pima County, Avra Valley, AZ}

Soiling Ratio > 99\% | Soiling Rate $=-0.05 \% /$ day June 02, 2013 to January 01, 2016

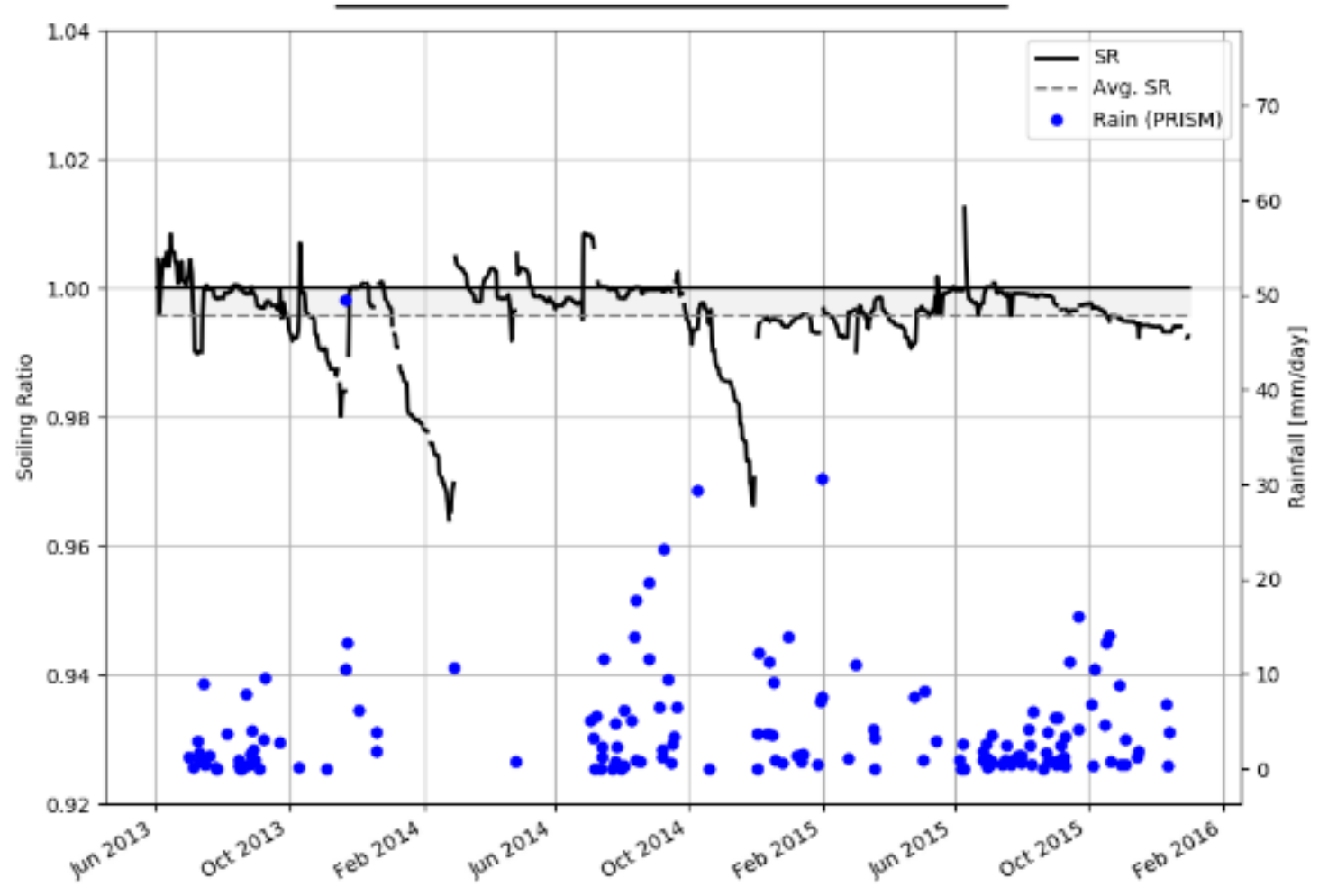




\section{Site 10 - Kern County, Meridian, CA}

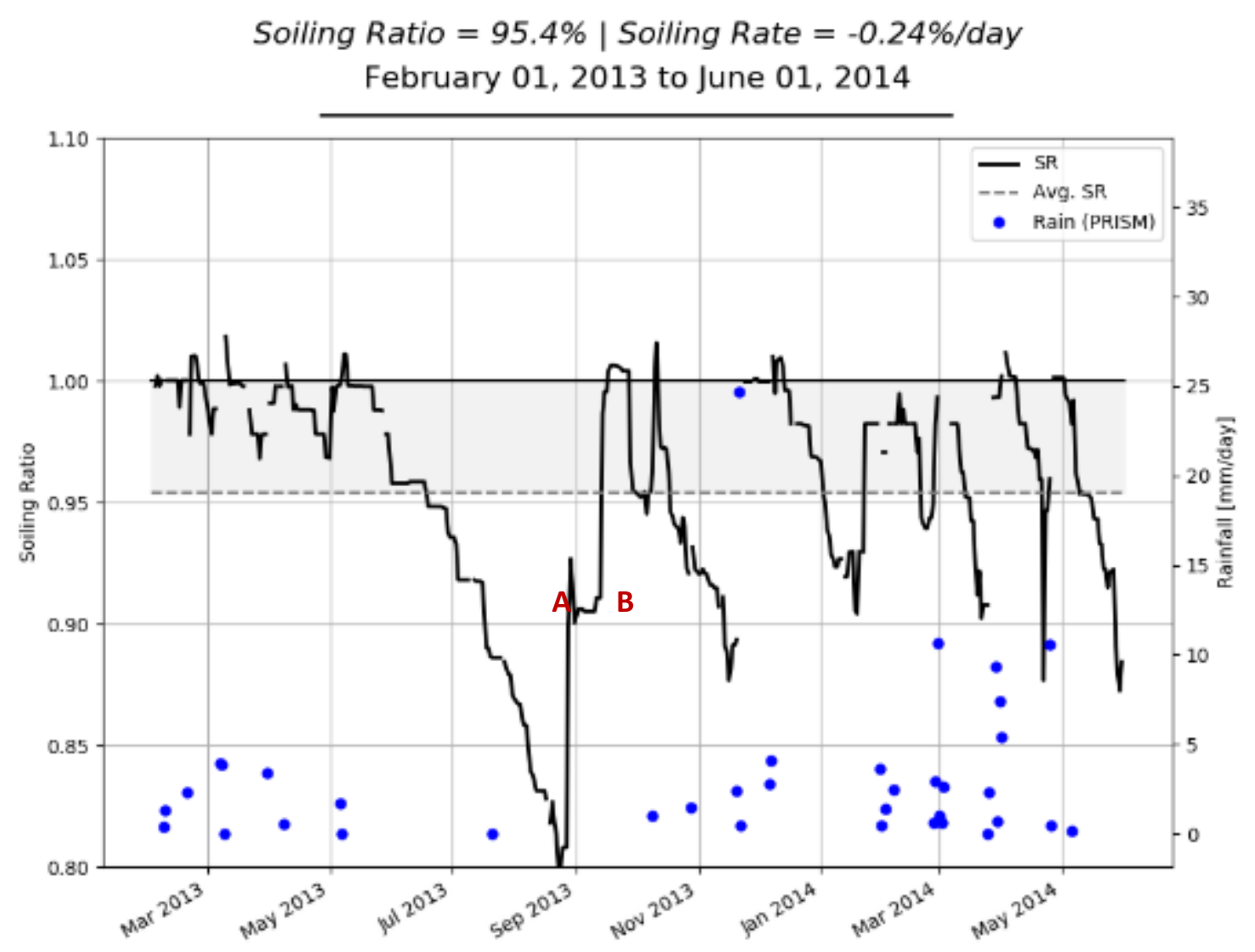




\section{Site 11 - Kern County, Lamont, CA}

Soiling Ratio $=94.9 \%$ | Soiling Rate $=-0.13 \% /$ day

February 01, 2013 to October 31, 2014

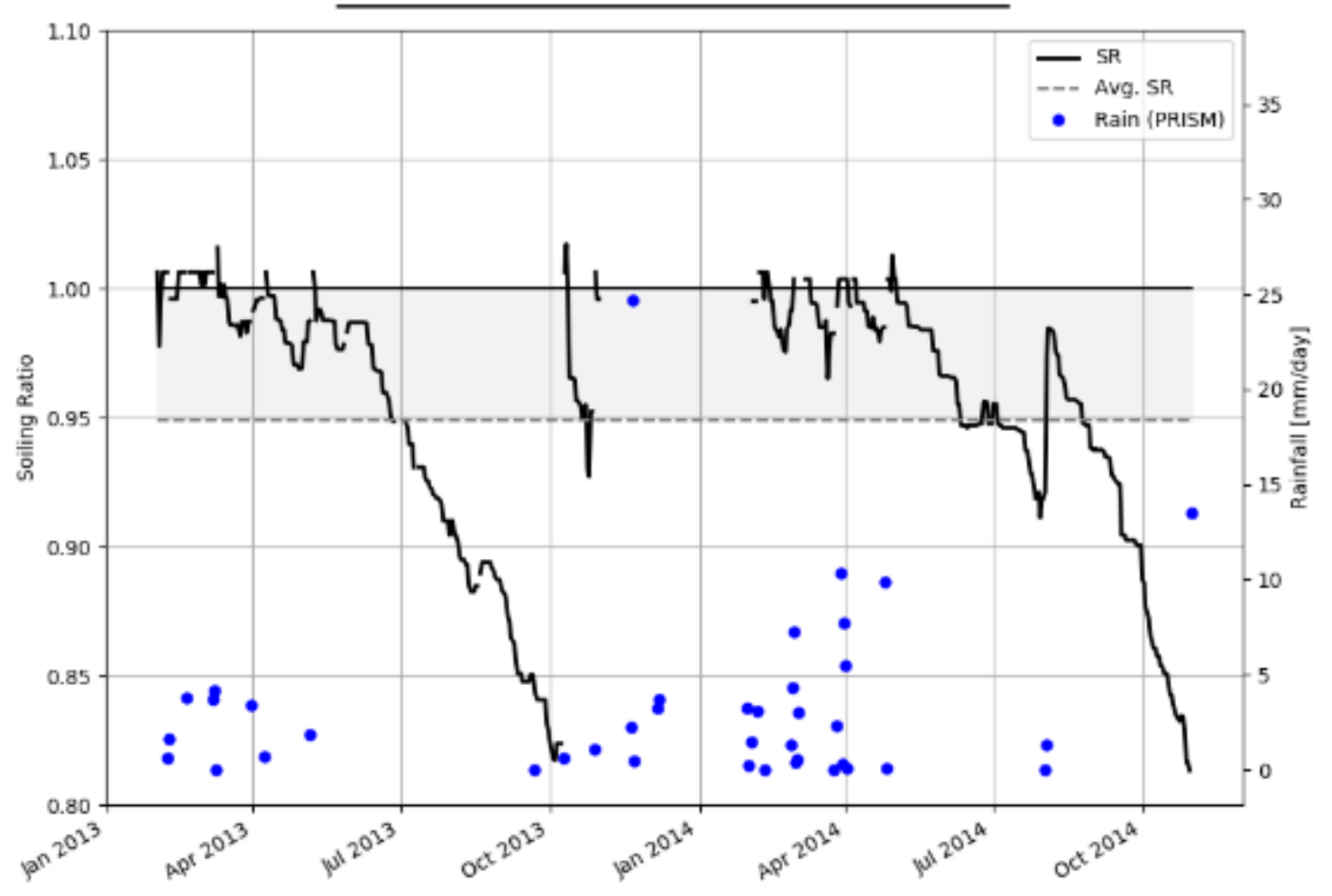




\section{Site 12 - Riverside County, Hemet, CA}

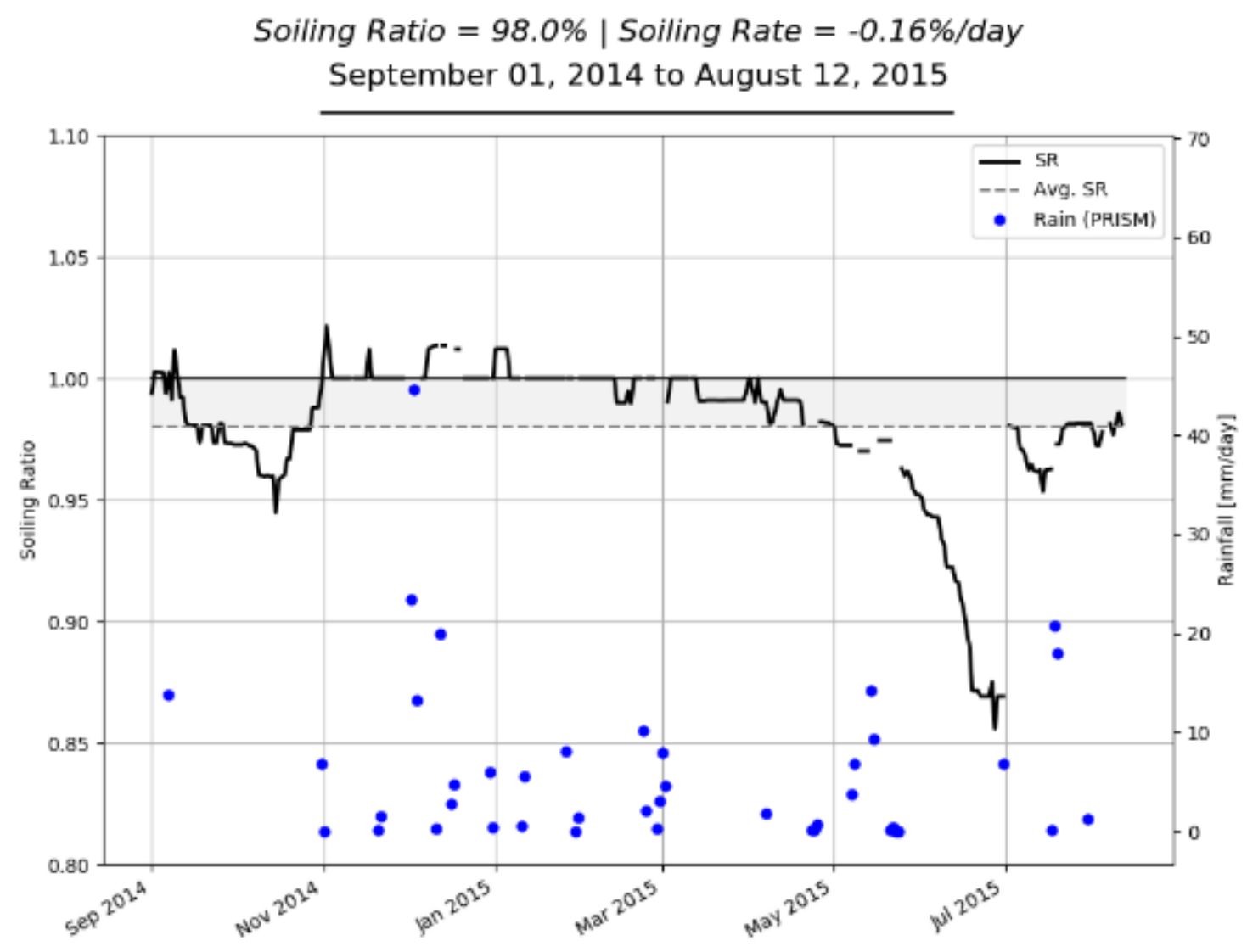




\section{Site 16 - Lancaster County, Actis, CA}

Soiling Ratio $=98.6 \%$ Soiling Rate $=-0.03 \% /$ day

December 01, 2013 to December 20, 2014

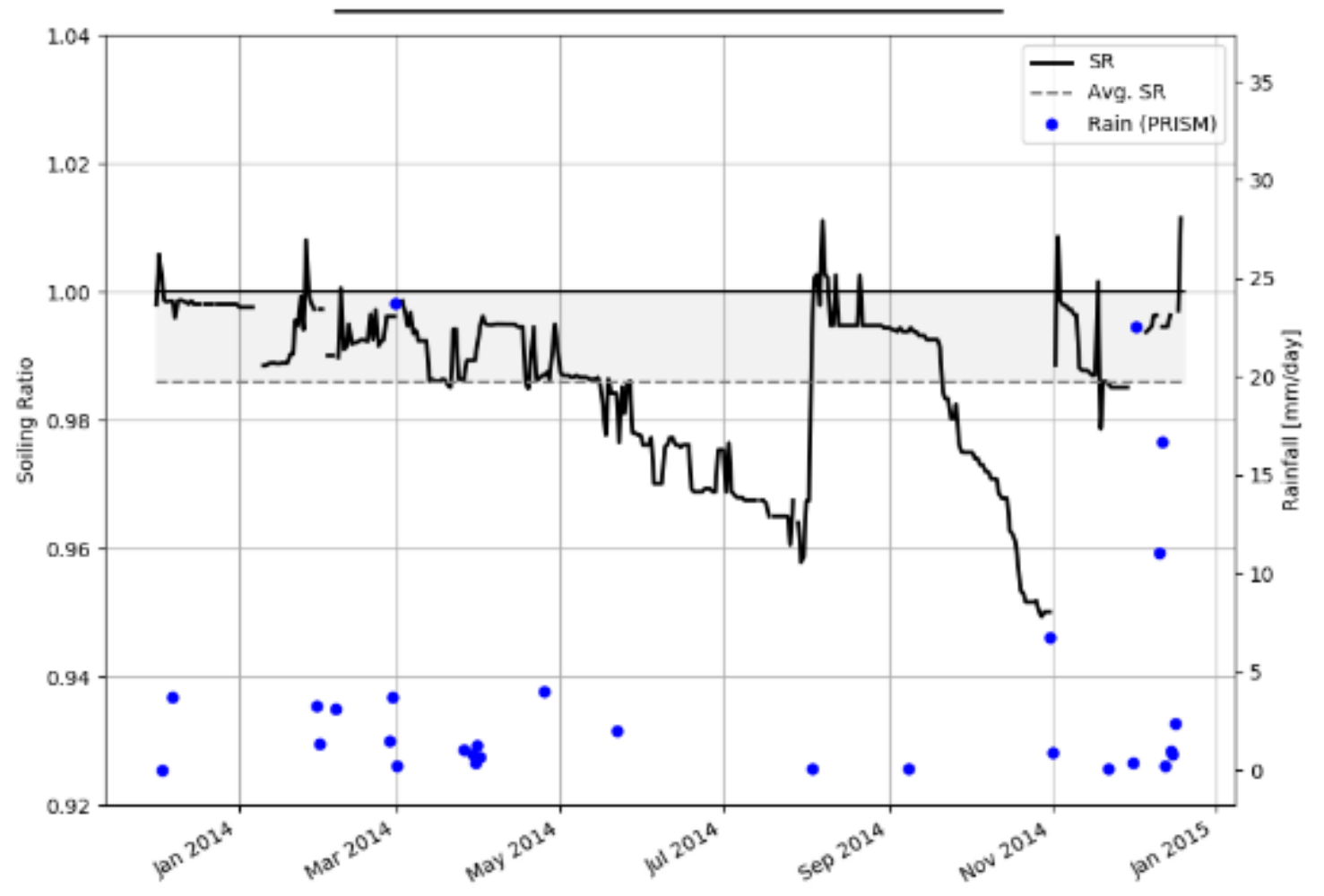




\section{Site 19 - Maricopa County, Gilbert, AZ}

Soiling Ratio > 99\% | Soiling Rate $=-0.06 \% /$ day

December 07, 2014 to September 22, 2016

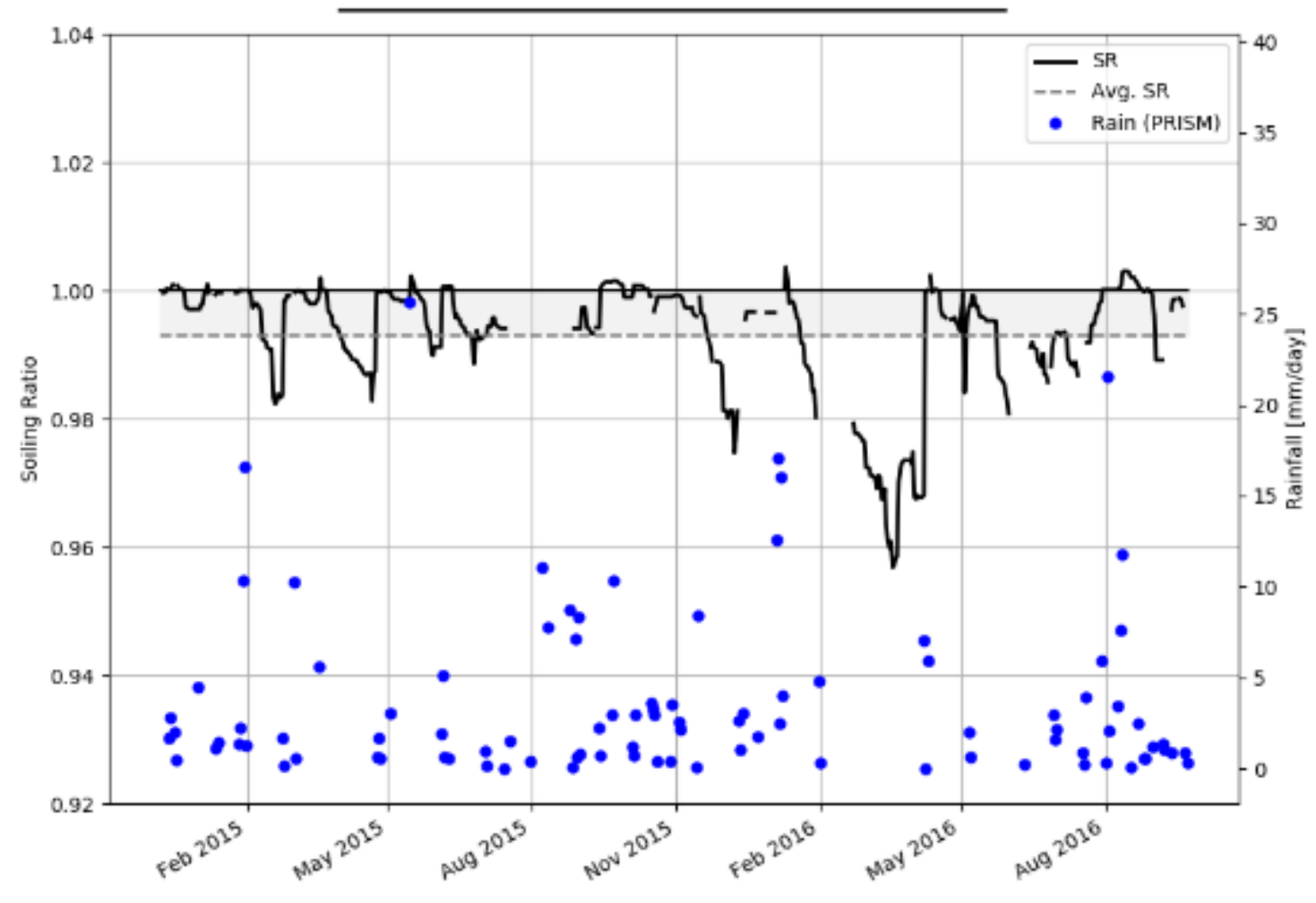

